\title{
Chronic overproduction of islet amyloid polypeptide/amylin in transgenic mice: lysosomal localization of human islet amyloid polypeptide and lack of marked hyperglycaemia or hyperinsulinaemia
}

\author{
J. W. M. Höppener ${ }^{1,2}$, J.S. Verbeek ${ }^{3}$, E.J.P.de Koning ${ }^{4,5}$, C. Oosterwijk $^{1}$, K.L. van Hulst ${ }^{2}$, H.J. Visser-Vernooy ${ }^{2}$, \\ F. M. A.Hofhuis ${ }^{3}$, S. van Gaalen ${ }^{3}$, M.J.H. Berends ${ }^{6}$, W.H.L.Hackeng ${ }^{7}$, H. S.Jansz ${ }^{1}$, J.F.Morris ${ }^{5}$, A. Clark ${ }^{4}$, \\ P.J.A.Capel ${ }^{3}$, C.J.M.Lips ${ }^{2}$
}

'Laboratory for Physiological Chemistry, Utrecht University, The Netherlands

${ }^{2}$ Department of Internal Medicine, Utrecht University, The Netherlands

${ }^{3}$ Department of Immunology, Utrecht University, The Netherlands

${ }^{4}$ Diabetes Research Laboratories, Radcliffe Infirmary, Oxford, UK

${ }^{5}$ Department of Human Anatomy, University of Oxford, UK

${ }^{6}$ Department of Pathology, Westeinde Hospital, The Hague, The Netherlands

${ }^{7}$ Practice for Laboratory Diagnosis, Geervliet, The Netherlands

\begin{abstract}
Summary. Type 2 (non-insulin-dependent) diabetes mellitus is characterised by hyperglycaemia, peripheral insulin resistance, impaired insulin secretion and pancreatic islet amyloid formation. The major constituent of islet amyloid is islet amyloid polypeptide (amylin). Islet amyloid polypeptide is synthesized by islet beta cells and co-secreted with insulin. The ability of islet amyloid polypeptide to form amyloid fibrils is related to its species-specific amino acid sequence. Islet amyloid associated with diabetes is only found in man, monkeys, cats and racoons. Pharmacological doses of islet amyloid polypeptide have been shown to inhibit insulin secretion as well as insulin action on peripheral tissues (insulin resistance). To examine the role of islet amyloid polypeptide in the pathogenesis of Type 2 diabetes, we have generated transgenic mice with the gene encoding either human islet amyloid polypeptide (which can form amyloid) or rat islet amyloid polypeptide, under control of an insulin promoter. Transgenic islet amyloid polypeptide mRNA was detected in the pancreas in all transgenic mice. Plasma islet amyloid polypeptide levels
\end{abstract}

were significantly elevated (up to 15 -fold) in three out of five transgenic lines, but elevated glucose levels, hyperinsulinaemia and obesity were not observed. This suggests that insulin resistance is not induced by chronic hypersecretion of islet amyloid polypeptide. Islet amyloid polypeptide immunoreactivity was localized to beta-cell secretory granules in all mice. Islet amyloid polypeptide immunoreactivity in beta-cell lysosomes was seen only in mice with the human islet amyloid polypeptide gene, as in human beta cells, and might represent an initial step in intracellular formation of amyloid fibrils. These transgenic mice provide a unique model with which to examine the physiological function of islet amyloid polypeptide and to study intracellular and extracellular handling of human islet amyloid polypeptide in pancreatic islets.

Key words: Islet amyloid polypeptide, amylin, transgenic mouse, islet beta cell, islet amyloid, glucose metabolism, insulin resistance, Type 2 (non-insulin-dependent) diabetes mellitus.
Diabetes associated islet amyloid occurs only in man, monkeys, cats and racoons but not in rats or mice. The major protein component of islet amyloid is islet amyloid polypeptide (IAPP) (amylin) [1-3]. IAPP is produced in islet beta cells and co-secreted with insulin in response to beta-cell secretagogues, although the amounts are several times lower [4-6]. It was shown that the amino acid sequence of a particular region of IAPP (amino acids 25-29) is important for amyloid fibril formation [7]. Non-amyloidogenic rat and mouse IAPP (which are identical) diverge considerably in this particular region from amyloidogenic IAPP molecules of e.g. man and cat. In the dog [8], rabbit and hare [9], the amino acid sequence of IAPP predicts amyloidogenicity, but islet amyloid has not been detected. In the dog IAPP-immunoreactive amyloid is associated with insulinoma [8], and in the rabbit and hare low levels of IAPP production may contribute to the lack of islet amyloid in these species [9]. The causative factors for amyloidogenesis of IAPP are unknown, but are not related to a genetically determined change in the amino acid sequence of IAPP or of its precursor (preproIAPP) [1, 10 12]. Overproduction, decreased breakdown or abnormal cellular handling of the peptide could be involved. The potential importance of IAPP overproduction is indicated by the occurrence of IAPP-immunoreactive amyloid in IAPP-overproducing insulinomas in man [1] and in the dog [8].

Until now, biological actions of human and rat IAPP have been described almost exclusively in short-term experiments using synthetic IAPP preparations at high concentrations. It was shown that IAPP can inhibit insulin secretion [13-16] and antagonize insulin action on glucose metabolism, in particular by inhibiting glycogen synthesis in skeletal muscle and stimulating glucose production from lactate by the liver [3, 17-21]. However, in some studies such effects of IAPP could not be demonstrated 
[22-28]. In Type 2 diabetes peripheral insulin resistance is often associated with obesity. Elevated plasma IAPP levels have been demonstrated in some obese glucose-intolerant patients [29], in glucose-intolerant first-degree relatives of Type 2 diabetic patients [30] and in animal models of diabetes [31-33]. Thus, an increase in production of IAPP might be important in the development of islet amyloid and of insulin resistance in Type 2 diabetes.

To test this hypothesis we generated transgenic mice which overproduce human (h) IAPP or rat (r) IAPP in their pancreatic beta cells. This represents a more natural and powerful model with which to study biological actions of native IAPP, produced in vivo in (supra)physiological amounts from pancreatic islet beta cells. This model allows the study of effects of chronically elevated plasma IAPP concentrations on glucose metabolism and on islet beta-cell function. In addition, transgenic mice producing hIAPP may represent a model for examination of factors involved in islet amyloid formation in vivo.

\section{Materials and methods}

\section{Generation of the transgenic constructs}

Plasmid RIP-DIP contains sequences from positions - 695 ( $\mathrm{BamHI}$ site) to +8 ( $X b a I$ site $)$ relative to the transcription start site of the rat insulin 2 gene $[34,35]$. RIP-1910 was derived from RIP-DIP and contains SalI linkers in the BamHI site at position -695 and in a BamHI site at a position approximately 50 base pairs (bp) downstream of the XbaI site. Plasmids containing the human (RIPhIAPP) or the rat (RIP-rIAPP) IAPP gene linked to the rat insulin 2 gene promoter fragment, were generated by ligation of suitable IAPP gene fragments $[36,37]$ (Fig. 1) in the $X b a I$ site of plasmid RIP-1910. The correct orientation of the IAPP gene fragments relative to the insulin gene promoter was confirmed by nucleotide sequence analysis.
Generation of the transgenic mice

Plasmids RIP-hIAPP and RIP-rIAPP were digested with SalI and the \pm 8.7 kilobase $(\mathrm{kb})$ and $\pm 8.3 \mathrm{~kb}$ fragments, containing the insulin promoter fragment linked to the IAPP gene fragments, were isolated and purified. These SalI fragments were used for microinjection into pronuclei of mouse zygotes, obtained from matings of $(\mathrm{C} 57 \mathrm{Bl} / 6 \mathrm{~J} \times \mathrm{CBA} / \mathrm{J}) \mathrm{F} 1$ males and females [38].

Mice which developed from injected zygotes were tested for transgene integration by Southern blot hybridization of chromosomal DNA isolated from tail biopsies [39]. The human transgene was detected with the $588 \mathrm{bp} E c o R I$ cDNA insert of clone $\lambda$ hIAPP-c1 [36], which does not hybridize to the endogenous mouse IAPP gene. The rat transgene was detected as a $2 \mathrm{~kb}$ TaqI fragment when hybridized to the $120 \mathrm{bp} A x y / / B a m H I$ fragment of the rat IAPP cDNA clone RPC-1 (nucleotides 11-130 in Fig. $1 \mathrm{~b}$ in [37]). This probe detects the mouse IAPP gene (nucleotide sequence homology is $93 \%$ ) as a $1 \mathrm{~kb}$ TaqI fragment. Southern blot positive mice (founders) and their transgenic offspring ( $\mathrm{F} 1$ ) were back-crossed to $\mathrm{C} 57 \mathrm{Bl} / 6 \mathrm{~J}$ mice and the F1 and $\mathrm{F} 2$ mice were used for the experiments described.

\section{$R N A$ isolation/Northern blot analysis}

Specimens of mouse tissues and of human and rat pancreas were snap frozen in liquid nitrogen and stored at $-80^{\circ} \mathrm{C}$. Total cellular RNA was isolated and analysed by Northern blotting as previously described [36]. The probes for detecting human and rat/mouse IAPP RNAs were as described for the Southern blot hybridizations. The human insulin probe, showing cross-hybridization to mouse insulin RNA, was a SmaI fragment with nucleotides 499 to 1250 of the human insulin gene [40]. Quantification of mRNAs was performed by densitometric scanning of autoradiographs, using an Ultroscan XL (LKB, Bromma, Sweden).

\section{Light microscopy}

Tissue from pancreas and kidney was fixed in $4 \%$ paraformaldehyde (weight/volume, w/v) in phosphate buffer ( $\mathrm{pH} 7.2$ ), dehydrated and embedded in wax. Sections were stained with a human-specific rab-
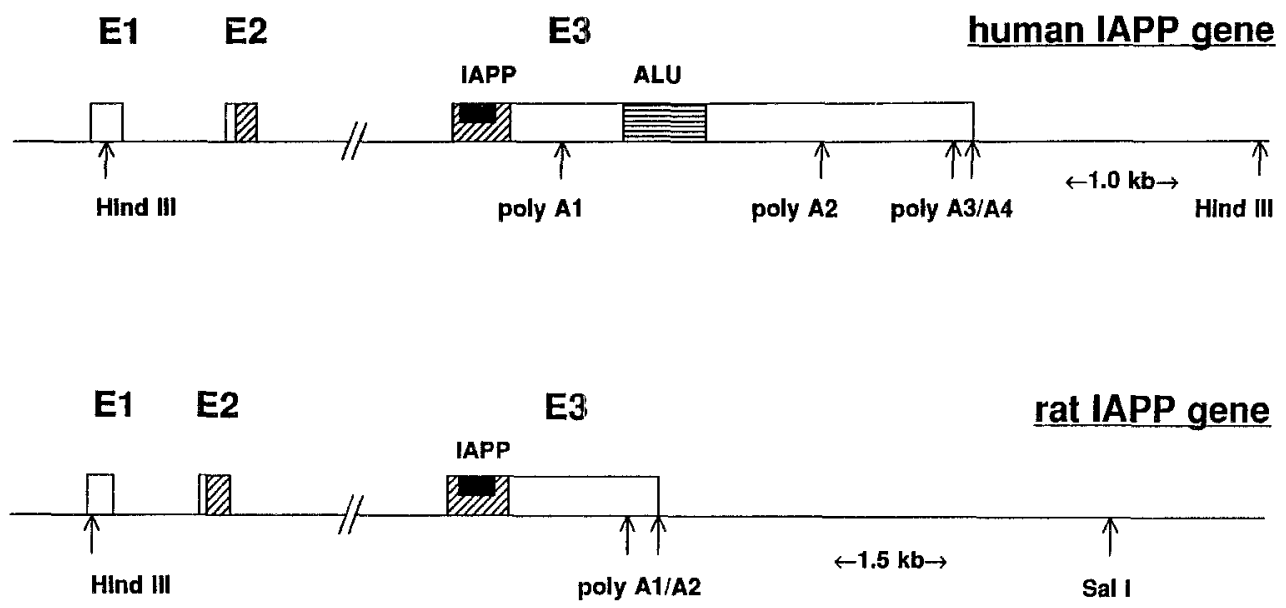

Fig. 1. Schematic representation of the human and rat IAPP genes. Exons are represented by numbered boxes, hatched parts indicate protein-encoding regions, black boxes indicate parts encoding the 37 amino acids of IAPP. Human IAPP and rat ( $=$ mouse) IAPP differ at 6 amino acid positions [10], 4 of which are in the amyloidogenic region 25-29 [7]. An Alu repetitive sequence in human IAPP exon 3 and identified polyadenylation signals are also indicated. The size of intron 1 is approximately 5 kilobases $(\mathrm{kb})$ in both genes. The $\pm 8.0 \mathrm{~kb}$ HindIII fragment of the human IAPP gene and the $\pm 7.6 \mathrm{~kb}$ HindIII/SalI fragment of the rat IAPP gene were cloned downstream of a 703 base pair rat insulin 2 gene promoter fragment. The resulting plasmids RIP-hIAPP and RIPrIAPP were digested with Sall and the $\pm 8.7 \mathrm{~kb}$ and $\pm 8.3 \mathrm{~kb}$ SalI fragments containing the insulin promoter/IAPP gene construct were used for generating transgenic mice. $E$ exon; $p o l y A$ polyadenylation signal 
bit antiserum (dilution 1:1200), biotin-conjugated swine anti-rabbit IgG (Dako, Glostrup, Denmark), peroxidase-conjugated streptavidin-biotin complex (Dako) and 3,3'-diaminobenzidine as substrate. The human-specific polyclonal rabbit antiserum was raised against the 16 amino acid peptide of proIAPP, which flanks IAPP at its carboxy terminus (K.L.v. H., unpublished data). This carboxyterminal flanking peptide is only $38 \%$ homologous between man and mouse [10]. IAPP immunostaining was performed with a polyclonal rabbit antiserum to hIAPP (1-37) (1:80) (Peninsula, Belmont, Calif., USA), which also detects rat and mouse IAPP. Specificity of the antisera was determined by lack of immunoreactivity following preabsorption with the carboxy-terminal flanking peptide and with hIAPP, respectively. For the detection of islet amyloid tissue sections were stained with sodium sulphate alcian blue (SAB), congo red or thioflavin S.

\section{Electron microscopy}

Fresh tissue samples of pancreas were cut into small pieces (approximately $1 \mathrm{~mm}^{3}$ ) and fixed immediately in $2.5 \%$ glutaraldehyde (v/v) in phosphate buffer ( $\mathrm{pH} 7.2$ ), post-fixed in $1 \%$ osmium tetroxide, dehydrated and embedded in Spurr's resin (Taab Laboratories, Reading, UK). IAPP was detected with a polyclonal rabbit antiserum to rat IAPP (1-37) (1:1000) (Peninsula) and protein A gold (Biocell, Cardiff, UK). The antiserum reacts with IAPP in beta cells of mouse, rat and human pancreatic islets. Specificity of the antiserum was determined by lack of immunoreactivity following preabsorption with human or rat IAPP (1-37). Contrast was enhanced with lead citrate and uranyl acetate. Specimens were examined for IAPP immunoreactivity with the investigators unaware of the genetic status of the animals.

\section{Blood analyses/radioimmunoassays}

Blood samples were taken from the retroorbital plexus of ether anaesthetised animals and collected in EDTA-tubes, which were kept on ice until centrifugation at $3500 \mathrm{rev} / \mathrm{min}$ for $5 \mathrm{~min}$ at $4{ }^{\circ} \mathrm{C}$. Plasma was taken and stored at $-80^{\circ} \mathrm{C}$ until determination of the levels of plasma IAPP, insulin and glucose. A radioimmunoassay (RIA) for determining IAPP concentrations in 50-100 $\mu$ l plasma samples was developed using acid-acetone extraction and a polyclonal rabbit

Figs. 2 A, B. Northern blot analysis of total cellular RNA $(30 \mu \mathrm{g})$ isolated from pancreas tissue and $(3 \mu \mathrm{g})$ from an insulinoma. A RNA from the pancreas of a control mouse $(m)$, of transgenic mice expressing the human IAPP transgene (derived from five different founders), of a non-diabetic human $(h)$ and from a human insulinoma ( $h i$ ). The 1600 and 2100 nucleotides human IAPP mRNAs are generated by usage of polyadenylation signals 2 and $3 / 4$ in the human IAPP gene respectively ([56], see Fig. 1). These RNAs were also detected in the mouse derived from founder \#28 and in normal human pancreas, but only after a longer exposure time (not shown). B RNA from the pancreas of a control mouse $(m)$, of transgenic mice expressing the rat IAPP transgene (derived from two different founders) and of a rat ( $r$ ). In the rat IAPP gene both polyadenylation signals (Fig. 1) are used in generation of mRNAs of approximately 1050 nucleotides [37]. Rat IAPP mRNAs were present in mice from both 'rat IAPP lines'. The blots of panel $\mathbf{A}$ and $\mathbf{B}$ were hybridized consecutively, by stripping and reprobing, to different probes (see Materials and methods). In mice of the 'human IAPP lines' transgenic IAPP mRNA was specifically detected by the human IAPP probe. Endogenous mouse IAPP mRNA ( 800 nucleotides) was detected by cross-hybridization to the rat IAPP probe. Endogenous mouse insulin mRNA was detected by cross-hybridization to the human insulin probe antiserum against hIAPP (1-37) (K.L.v.H., unpublished data). Equal volumes of plasma and acid-acetone were mixed and after centrifugation the IAPP-containing supernatant was freeze-dried and resuspended in $250 \mu \mathrm{l}$ assay buffer. A $200 \mu \mathrm{l}$ sample was incubated with the primary antiserum for $90 \mathrm{~h}$ at $4^{\circ} \mathrm{C}$. Then $5000 \mathrm{cpm}^{125} \mathrm{I}-$
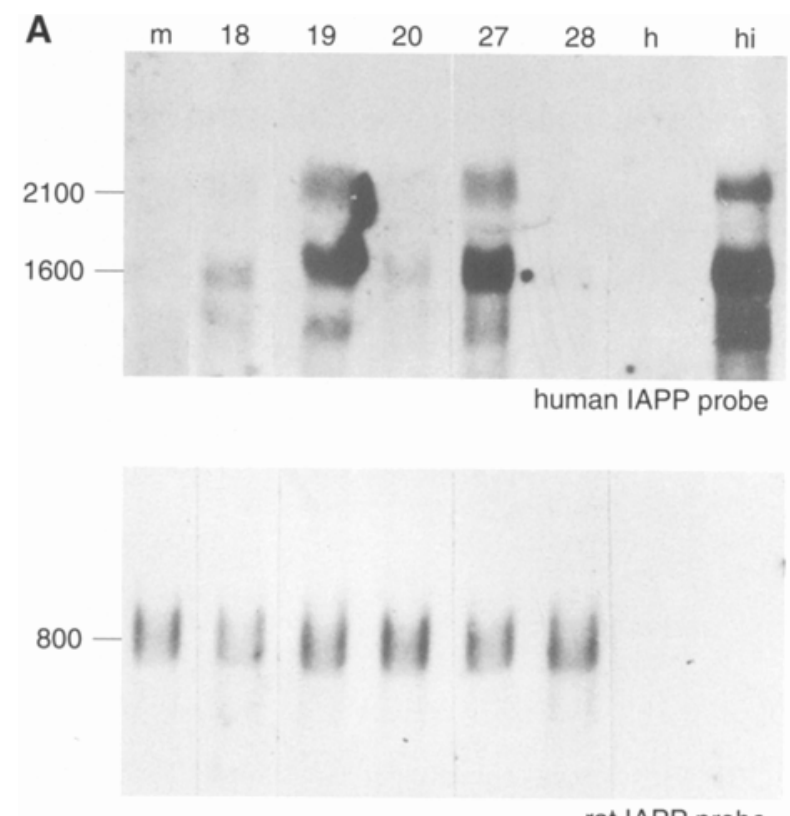

rat IAPP probe
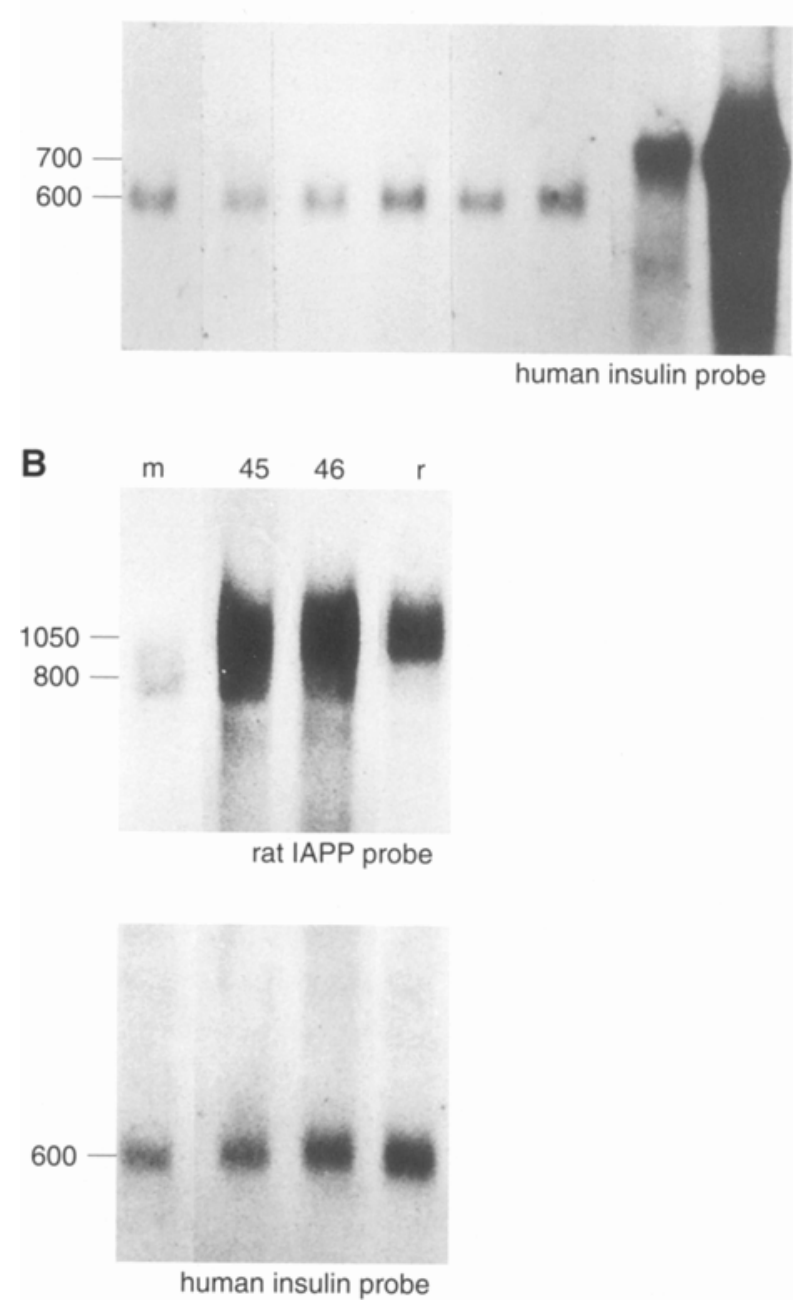
IAPP (Peninsula) was added and the incubation continued for another $48 \mathrm{~b}$ at $4^{\circ} \mathrm{C}$. A second (goat-anti-rabbit) antiserum was added and incubated for $4 \mathrm{~h}$ at $4{ }^{\circ} \mathrm{C}$. Immune-complexes were precipitated and the ratio bound/not bound ${ }^{125}$ I-IAPP was calculated. The recovery of synthetic IAPP in this procedure (extraction plus RIA) was $82 \pm 6 \%$ (range $73-94 \%, n=16$ ) and the minimal detection limit was $2.3 \pm 0.1$ femtomol (fmol) per sample. Intra-assay variation was $16.3 \%(4.3 \mathrm{pmol} / \mathrm{l})$ to $6.2 \%(32.0 \mathrm{pmol} / \mathrm{l})(n=10)$ and interassay variation was $12.2 \%(4.1 \mathrm{pmol} / 1)$ to $7.4 \%(29.7 \mathrm{pmol} / \mathrm{l})(n=8)$. The cross-reactivity in this RIA of rat (=mouse) IAPP is $100 \%$. Thus, the sum of endogenous mouse IAPP and transgenic IAPP was measured. Plasma insulin concentrations were measured by RIA in duplicate using $50 \mu \mathrm{l}$ samples and a polyclonal guinea pig antiserum against swine insulin [41]. The recovery in this RIA was approximately $95 \%$ and the sensitivity was 1 fmol per sample. Because the actual degree of cross-reactivity with mouse insulin was unknown, we have expressed plasma insulin levels as pmol equivalents of swine insulin per litre (pmolE/ ). Plasma glucose levels were determined in $50 \mu 1$ samples using the hexokinase method [42].

\section{Statistical analyses}

Since plasma IAPP levels were not normally distributed within the transgenic lines, statistical calculations for investigating differences in plasma IAPP levels, plasma insulin or glucose levels between the different groups of mice (transgenic and control) were performed using the non-parametric Kruskal-Wallis Test and Multiple Comparison $\mathrm{Z}$-Values $(\mathrm{Z}>1.96)$.

To investigate relations between plasma levels of IAPP and plasma levels of insulin or glucose of individual animals within each of these groups of mice, multiple regression analysis was performed. Multiple regression analysis was also used to compare the body weights between the different groups of mice. The limit of significance was set at $p=0.05$.

\section{Results}

Seven mice which were Southern blot positive for the human construct and two for the rat construct were obtained (founders). Tissue specific expression of the transgenes was examined by Northern blot analysis of RNA isolated from different tissues. Human IAPP mRNAs of 2100 and 1600 nucleotides were detected in the pancreas of all mice with the human construct, whereas rIAPP mRNA of 1050 nucleotides was detected in the pancreas of all mice with the rat construct (Fig. 2). As compared to normal human pancreas, hIAPP mRNAs were more abundant (422 fold) in the pancreas of hIAPP transgenic mice. The level of expression was highly variable between mice from different founders (Fig. 2A), but was not related to the transgene copynumber (5-25, data not shown). As compared to normal rat pancreas, rIAPP mRNA was two- to three-fold more abundant in the pancreas of rIAPP transgenic mice (Fig.2B). The levels of endogenous mouse IAPP mRNA and insulin mRNA in the pancreas were apparently not influenced by expression of the human or rat IAPP transgene (Figs. $2 \mathrm{~A}$ and 2B). Three hIAPP lines ( \# 18, \# 19 and \# 20) and tworlAPPlines ( \# 45 and \# 46) were established and mice from 21-63 weeks of age were used for further characterization. Transgenic RNA was also detected in the kidney, except for mice of line \# 45. No IAPP RNA was detected in brain,liver, spleen, stomach, heart, lung, salivary gland or urogenital tract.
Table 1. Median of plasma IAPP, insulin and glucose levels of nonfasted transgenic and control mice

\begin{tabular}{llccc}
\hline Line & $n$ & IAPP $(\mathrm{pmol} / \mathrm{l})$ & Insulin $(\mathrm{pmolE} / \mathrm{l})$ & Glucose $(\mathrm{mmol} / \mathrm{l})$ \\
\hline$\# 18$ & $2 \mathrm{f} / 2 \mathrm{~m}$ & $258(146-380)^{\mathrm{a}}$ & $80(29-102)$ & $9.3(7.9-10.2)$ \\
$\# 19$ & $4 \mathrm{f} / 2 \mathrm{~m}$ & $122(69-218)^{\mathrm{a}}$ & $80(65-145)$ & $8.2(7.2-10.6)$ \\
$\# 20$ & $2 \mathrm{f} / 2 \mathrm{~m}$ & $53(37-105)$ & $87(44-123)$ & $10.9(8.5-13.7)$ \\
$\# 45$ & $2 \mathrm{f} / 3 \mathrm{~m}$ & $63(24-170)$ & $102(22-109)$ & $9.5(8.8-13.1)$ \\
$\# 46$ & $2 \mathrm{f} / 2 \mathrm{~m}$ & $463(351-665)^{\mathrm{a}}$ & $65(29-73)$ & $9.4(8.5-9.7)$ \\
Con & $5 \mathrm{f} / 5 \mathrm{~m}$ & $32(14-42)$ & $73(36-102)$ & $10.1(7.9-12.7)$ \\
\hline
\end{tabular}

${ }^{a} p<0.05$ vs control mice. Con, Non-transgenic controls (littermates); $n$, number of animals investigated; $\mathrm{f}$, female mice; $\mathrm{m}$, male mice. Range is indicated in parentheses. pmolE/, pmol equivalents of swine insulin per litre

Translation of transgenic hIAPP mRNA was investigated by immunohistochemistry, using an antibody raised against the carboxy-terminal flanking peptide to hIAPP. This antibody immunostained beta cells in human pancreas and in hIAPP transgenic mouse pancreas, but not in rIAPP transgenic or control mouse pancreas, thus confirming the production of transgenic human protein (Figs. 3 A-D). Stronger IAPP immunostaining of beta cells in rIAPP transgenic mice as compared to non-transgenic control mice, indicated translation of transgenic IIAPP mRNA in the pancreas. In the kidney specific IAPP immunoreactivity could not be detected, except for rIAPP transgenic mice of line \# 46 where IAPP was localized to proximal tubular cells (data not shown).

Plasma levels of IAPP were significantly elevated in mice from three transgenic lines ( \#18, \#19 and \#46), as compared to non-transgenic mice of the same genetic background (Table 1). In some animals a more than 15fold elevated plasma IAPP concentration was measured. As indicated by the large range-values in Table 1, the plasma IAPP levels varied greatly between mice within the same line. Due to this variation the elevation of plasma IAPP levels in lines \# 20 and \# 45 was not statistically significant compared to control mice.

Plasma insulin or glucose levels were not significantly different between the transgenic mice and controls (Table 1). Also, within each of the transgenic lines there was no significant correlation between plasma levels of IAPP and insulin or glucose from individual mice.

Body weights of animals between 20 and 60 weeks of age were not significantly different between transgenic mice ( $n \geq 12$ for each of the lines) and controls $(n=39)$.

Amyloid deposits were not detected in hIAPP transgenic mice ( $n=6-8$ for each of the three lines) or rIAPP transgenic mice ( $n=6$ for both lines) or in non-transgenic control mice $(n=16)$, up to 63 weeks of age. As a positive control, islet amyloid was detected in the pancreas of a patient with Type 2 diabetes. At the subcellular level, IAPP immunoreactivity was localized to beta-cell secretory granules in all mice examined, both transgenic for hIAPP $(n=12)$ or rIAPP $(n=8)$ and non-transgenic $(n=10)$. However, the highest level of immunoreactivity was observed in beta-cell lysosomal bodies in all hIAPP transgenic mice ( $n=4$ for each line) (Fig. 4). IAPP immunoreactivity in lysosomes was not seen in similarly aged nontransgenic mice nor in mice expressing the rIAPP transgene ( $n=4$ for each of the two lines). 

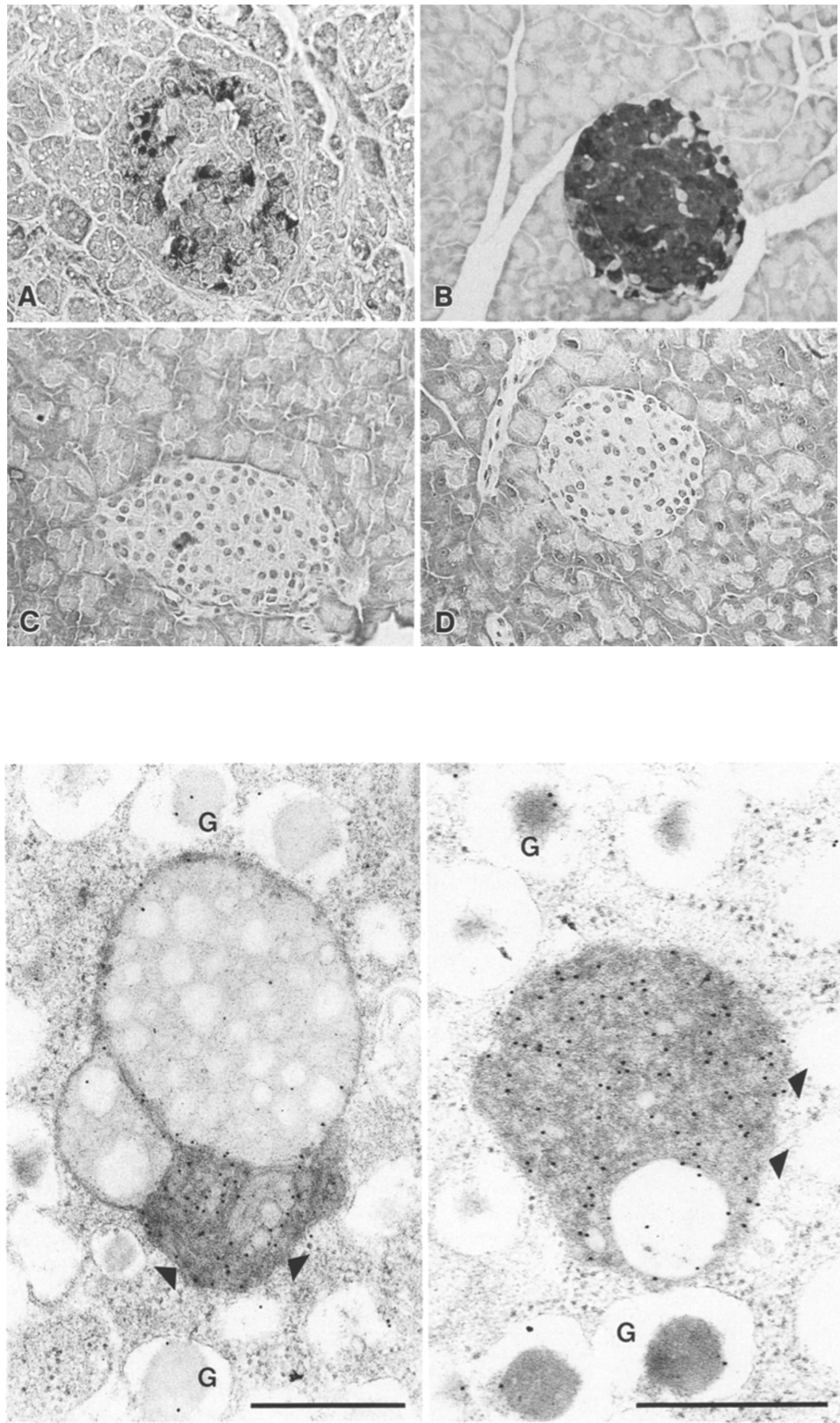

Figs.3A-D. Detection of human IAPP gene encoded protein in pancreas tissue by immunohistochemical staining with an antiserum raised against the carboxy-terminal flanking peptide to human IAPP. Immunoreactivity was limited to islet beta cells of $(\mathbf{A})$ human and (B) human IAPP transgenic mouse pancreas (from line \#19), but was not detected in (C) control mouse or (D) rat IAPP transgenic mouse pancreas (from line \#45). Magnification: $\times 200$
Fig. 4. Subcellular localization of IAPP in islets of human IAPP transgenic mice, using electron microscopy and immunogold labelling. Secretory granules $(G)$ in beta cells of all transgenic and control mice showed immunoreactivity. In addition a much stronger immunoreactivity was observed in beta-cell lysosomal bodies ( $a r$ rows) only in animals producing human IAPP. Scale bar $=0.5 \mu \mathrm{m}$ 


\section{Discussion}

The rat insulin 2 gene promoter/LAPP gene constructs directed the production of high levels of transgenic IAPP mRNA in the pancreas of most transgenic mice. Exact quantitative comparisons between transgenic and endogenous mouse IAPP mRNA levels per beta cell are difficult, due to differences in nature and specific activity of the probes used. Furthermore, differences in islet density between human, rat and mouse pancreas confound these comparisons. Downregulation of the endogenous mouse IAPP gene was not observed in any of the transgenic lines. Downregulation of the endogenous mouse insulin gene was also not seen despite the presence of multiple copies of the transgenic constructs containing the rat insulin 2 gene promoter fragment, which might compete for common transcription factors. Using immunohistochemistry, translation of transgenic IAPP mRNA in the pancreas was confirmed.

Transgenic RNA was also detected in the kidney, as previously described for other rat insulin 2 gene promoter/transgene constructs [43, 44]. This 'ectopic' expression is probably due to the nature of the rat insulin 2 gene upstream region in the constructs used. Thus, upstream of position -695 relative to the transcription start site, sequences might be located which prevent activity of the rat insulin 2 gene promoter in tissues other than the pancreas. Translation of transgenic IAPP RNA in the kidney could be demonstrated only in mice of line \#46, which express the rIAPP transgene.

Reported circulating IAPP levels are 5-15 pmol/l in man [45] or 55-90 pmol/1 in mouse [46]. However, for hyperinsulinaemic ob/ob and $\mathrm{db} / \mathrm{db}$ mice, plasma IAPP levels up to $290 \mathrm{pmol} / /$ have been reported [46]. In other animal models of obesity and diabetes high circulating levels of both IAPP and insulin have also been reported $[47,48]$. In man both plasma IAPP and insulin levels are higher in some obese, glucose-intolerant subjects than in controls [29, 30]. Apparently, IAPP and insulin secretion are co-ordinately regulated in fasting [49], as well as in obesity and diabetes. In our mouse model the level of transgene expression is independent of endogenous mouse insulin gene expression. Thus, effects of elevated plasma IAPP levels on insulin secretion could be examined, as well as other effects which might be due to elevated plasma IAPP levels irrespective of high insulin levels.

Our data show that IAPP exerts no obvious long-term effect on insulin gene expression or insulin secretion by beta cells at (supra)physiological concentrations of the native peptide (median 53-463 pmol/l). This is in accordance with several in vitro and in vivo studies, which failed to demonstrate an effect of IAPP on insulin biosynthesis or secretion, even at concentrations of $100 \mathrm{nmol} / \mathrm{1}[22-25]$. In some short-term studies IAPP-induced inhibition of insulin secretion has been demonstrated, mostly at pharmacological concentrations of $0.1-10 \mu \mathrm{mol} / 1$ [13-15] but, more recently, also at a concentration of $75 \mathrm{pmol} / \mathrm{l}$ [16]. However, changes of insulin secretion in a situation of chronically elevated IAPP concentrations have not yet been explored.
Hyperglycaemic effects of IAPP described in the literature have been established at very high concentrations (mostly at least $1 \mathrm{nmol} / \mathrm{l}$ ) of synthetic human or rat IAPP $[3,17-21]$. We did not observe elevated plasma glucose levels in any of our transgenic lines, at plasma IAPP levels ranging from 53 to $463 \mathrm{pmol} / \mathrm{l}$ (median). This does not exclude a local effect of IAPP on glucose metabolism in skeletal muscle or liver, which might not result in longterm elevated plasma glucose levels due to counterregulation. In theory, both an inhibitory effect on insulin secretion (direct effect of IAPP on beta cells) and a stimulatory influence on insulin secretion (due to IAPP-induced insulin resistance in peripheral tissues) might counterbalance each other without an obvious effect on plasma insulin levels. However, the resulting insulin level would probably be insufficient to prevent elevated glucose levels as a consequence of the insulin resistance.

Type 2 diabetes is an age-related disease which is usually not diagnosed before the age of 40 years and which may have very diverse pathogenic origins [50]. As demonstrated in diabetic man [51] and diabetic monkeys [52], the extent of islet amyloid formation increases with disease severity. Formation of insoluble amyloid deposits around capillaries is likely to be involved in the progressive deterioration of islet function. Although islet amyloid in diabetic man and diabetic animals is found predominantly extracellularly, there are several indications suggesting that amyloid fibrils might result from accumulation of IAPP at intracellular sites [53]. The highest density of IAPP immunoreactivity was localized to beta-cell lysosomal bodies in human IAPP transgenic mice, as in man [54]. In human insulinoma cells intracellular IAPP. immunoreactive amyloid fibrils have been demonstrated [55]. If amyloid fibril formation in pancreatic islets occurs as a consequence of accumulation of IAPP, lysosomal bodies would represent a potential intracellular site for the initiation of amyloidogenesis, in particular since both lysosomal accumulation and amyloid fibril formation are related to the amino acid sequence of IAPP. Deposits of islet amyloid were not found in hIAPP transgenic mice up to the age of 63 weeks, but might develop later in life. Alternatively, mice simply do not grow old enough to develop islet amyloid deposits as we know them in man or perhaps additional factors, such as those present in diabetes, are required for islet amyloidogenesis (e.g. hyperglycaemia or hyperinsulinaemia or both).

In conclusion, our present data indicate that chronically elevated IAPP levels per se do not inhibit insulin biosynthesis and do not cause elevated glucose levels, hyperinsulinaemia or obesity, suggesting no insulin resistance, in mice up to 63 weeks old. Human IAPP is handled by transgenic mouse beta cells in a similar manner as by human beta cells, causing accumulation of IAPP within lysosomal bodies. Further studies are needed to investigate whether this lysosomal pathway can lead to fibrillogenesis and amyloidogenesis. In the pathogenesis of Type 2 diabetes, increased production of IAPP may induce and/or contribute to progressive amyloid formation, which in the long term may lead to beta-cell dysfunction, insufficient insulin secretion and hyperglycaemia. The overproduction of human IAPP in this transgenic mice 
model offers a unique opportunity to study the biosynthesis, intracellular handling, secretion and extracellular handling of human IAPP in vivo.

Acknowledgements. The authors wish to thank Dr. A.D.M. van Mansfeld (Utrecht University, The Netherlands) for providing the rat IAPP genomic clone $\lambda R G 1$, Dr. D. Hanahan (University of California, San Francisco, Calif., USA) for the rat insulin 2 gene promotor plasmid RIP-DIP, Mr. H. Flamman, Ms. M.Klink, Mr. T. Hesp, Mr. R. Timmermans and Mr. G. Peek for technical assistance and Dr. A.D.M. van Mansfeld, Professor P.C. van der Vliet and Professor D.W.Erkelens for critical reading of the manuscript. This research was supported by the Royal Dutch Academy of Sciences (KNAW) (J.W.M.H.), the Netherlands Organization for Chemical Research (SON) with financial aid from the Netherlands Organization for Scientific Research (NWO) (C.O.), the Diabetes Fund the Netherlands (DFN) (K.L.v.H.), the British Diabetic Association (BDA) (A.C.), the Oxford University Research Fund and the Medical Research Council (MRC) (E. J.P. de K.).

\section{References}

1. Westermark P, Wernstedt C, Wilander E, Hayden DW, O'Brien TD, Johnson KH (1987) Amyloid fibrils in human insulinoma and islets of Langerhans of the diabetic cat are derived from a neuropeptide-like protein also present in normal islet cells. Proc Natl Acad Sci USA 84: 3881-3885

2. Cooper GJS, Willis AC, Clark A, Turner RC, Sim RB, Reid KBM (1987) Purification and characterization of a peptide from amyloid-rich pancreases of type 2 diabetic patients. Proc Natl Acad Sci USA 84: 8628-8632

3. Cooper GJS, Leighton B, Dimitriadis GD et al. (1988) Amylin found in amyloid deposits in human type 2 diabetes mellitus may be a hormone that regulates glycogen metabolism in skeletal muscle. Proc Natl Acad Sci USA 85: 7763-7766

4. Johnson KH, O'Brien TD, Betsholtz C, Westermark P (1989) Islet amyloid, islet amyloid polypeptide, and diabetes mellitus. N Engl J Med 321: 513-518

5. Ferrier GJM, Pierson AM, Jones PM, Bloom SR, Girgis SI, Legon S, (1989) Expression of the rat amylin (IAPP/DAP) gene. J Mol Endocrinol 3: R1-R4

6. Kahn SE, D'Alessio DA, Schwartz MW et al. (1990) Evidence of cosecretion of islet amyloid polypeptide and insulin by beta-cells. Diabetes 39: 634-638

7. Westermark P, Engström U, Johnson KH, Westermark GT, Betsholtz C (1990) Islet amyloid polypeptide: pinpointing amino acid residues linked to amyloid fibril formation. Proc Natl Acad Sci USA 87: 5036-5040

8. O'Brien TD, Westermark P, Johnson KH (1990) Islet amyloid polypeptide and calcitonin gene-related peptide immunoreactivity in amyloid and tumor-cells of canine pancreatic endocrine tumors. Vet Pathol 27: 194-198

9. Christmanson L, Betsholtz C, Leckström A et al. (1993) Islet amyloid polypeptide in the rabbit and European hare: studies on its relationship to amyloidogenesis. Diabetologia 36: 183-188

10. Nishi M, Chan SJ, Nagamatsu S, Bell GI, Steiner DF (1989) Conservation of the sequence of islet amyloid polypeptide in five mammals is consistent with its putative role as an islet hormone. Proc Natl Acad Sci USA 86: 5738-5742

11. Mosselman S, Höppener JWM, Zandberg J et al. (1988) Islet amyloid polypeptide: identification and chromosomal localization of the human gene. FEBS Lett 239: 227-232

12. Nishi M, Bell GI, Steiner DF (1990) Islet amyloid polypeptide (amylin): no evidence of an abnormal precursor sequence in 25 type 2 (non-insulin-dependent) diabetic patients. Diabetologia 33: $628-630$

13. Ohsawa $\mathrm{H}, \mathrm{Kanatsuka} A$, Yamaguchi T, Makino H, Yoshida S (1989) Islet amyloid polypeptide inhibits glucose-stimulated in- sulin secretion from isolated rat pancreatic islets. Biochem Biophys Res Commun 160: 961-967

14. Silvestre RA, Peiro E, Dégano P, Miralles P, Marco J (1990) Inhibitory effect of rat amylin on the insulin responses to glucose and arginine in the perfused rat pancreas. Regul Pept 31:23-31

15. Kogire M, Ishizuka J, Thompson JC, Greely GH Jr (1991) Inhibitory action of islet amyloid polypeptide and calcitonin gene-related peptide on release of insulin from the isolated perfused rat pancreas. Pancreas 6: 459-463

16. Dégano P, Silvestre RA, Salas M, Peiro E, Marco J (1993) Amylin inhibits glucose-induced insulin secretion in a dose-dependent manner - Study in the perfused rat pancreas. Regul Pept 43: 91-96

17. Leighton B, Cooper JS (1988) Pancreatic amylin and calcitonin gene-related peptide cause resistance to insulin in skeletal muscle in vitro. Nature 335: 632 -635

18. Johnson KH, O'Brien TD, Jordan K, Betsholtz C, Westermark P (1990) The putative hormone islet amyloid polypeptide (IAPP) induces impaired glucose-tolerance in cats. Biochem Biophys Res Commun 167: 507-513

19. Molina JM, Cooper GJS, Leighton B, Olefsky JM (1990) Induction of insulin resistance in-vivo by amylin and calcitonin generelated peptide. Diabetes 39:260-265

20. Sowa R, Sanke T, Hirayama J et al. (1990) Islet amyloid polypeptide amide causes peripheral insulin resistance in vivo in dogs. Diabetologia 33: 118-120

21. Koopmans SJ, van Mansfeld ADM, Jansz HS et al. (1991) Amylin-induced in-vivo insulin resistance in conscious rats: the liver is more sensitive to amylin than peripheral tissues. Diabetologia 34: 218-224

22. Bretherton-Watt D, Gilbey SG, Ghatei MA, Beacham J, Bloom SR (1990) Failure to establish islet amyloid polypeptide (amylin) as a circulating beta cell inhibiting hormone in man. Diabetologia 33: $115-117$

23. O'Brien TD, Westermark P, Johnson KH (1990) Islet amyloid polypeptide (IAPP) does not inhibit glucose-stimulated insulinsecretion from isolated perfused rat pancreas. Biochem Biophys Res Commun 170: 1223-1228

24. Nagamatsu S, Carroll RJ, Grodsky GM, Steiner DF (1990) Lack of islet amyloid polypeptide regulation of insulin biosynthesis or secretion in normal rat islets. Diabetes 39: 871-874

25. Broderick CL, Brooke GS, DiMarchi RD, Gold G (1991) Human and rat amylin have no effects on insulin-secretion in isolated rat pancreatic-islets. Biochem Biophys Res Commun 177: 932-938

26. Kassir AA, Upadhyay AK, Lim TJ, Moosa AR, Olefsky JM (1991) Lack of effect of islet amyloid polypeptide in causing insulin resistance in conscious dogs during euglycaemic clamp studies. Diabetes 40: 998-1004

27. Ghatei MA, Datta HK, Zaidi M et al. (1990) Amylin and amylinamide lack an acute effect on blood glucose and insulin. J Endocrinol 124: R9-R11

28. Tedstone AE, Nezzer T, Hughes SJ, Clark A, Matthews DR (1990) The effect of islet amyloid polypeptide (amylin) and calcitonin gene-related peptide on glucose removal in the anaesthetized rat and on insulin secretion from rat pancreatic islets in vitro. Biosci Rep 10: 339-345

29. Ludvik B, Svoboda T, Hartter E et al. (1990) Basal and stimulated amylin levels in diabetes mellitus. Diabetologia 33: A39 (Abstract)

30. Eriksson J, Nakazato M, Miyazato M, Shiomi K, Matsukura S, Groop L (1992) Islet amyloid polypeptide: plasma-concentrations in individuals at increased risk of developing type 2 (noninsulin-dependent) diabetes mellitus. Diabetologia 35:291-293

31. Bretherton-Watt D, Ghatei MA, Bloom SR et al. (1989) Altered islet amyloid polypeptide (amylin) gene expression in rat models of diabetes. Diabetologia 32: 881-883

32. Gedulin B, Cooper GJS, Young AA (1991) Amylin secretion from the perfused pancreas: dissociation from insulin and abnormal elevation in insulin-resistant diabetic rats. Biochem Biophys Res Commun 180: 782-789 
33. Inoue K, Hisatomi A, Umeda F, Nawata H (1992) Effects of exogenous somatostatin and insulin on islet amyloid polypeptide (amylin) release from perfused rat pancreas. Hormone Metab Res 24: 251-253

34. Hanahan D (1985) Heritable formation of pancreatic $\beta$-cell tumours in transgenic mice expressing recombinant insulin/simian virus 40 oncogenes. Nature $315: 115-122$

35. Bento Soares M, Schon E, Henderson A et al. (1985) RNAmediated gene duplication: the rat preproinsulin I gene is a functional retroposon. Mol Cell Biol 5: 2090-2103

36. Mosselman S, Höppener JWM, Lips CJM, Jansz HS (1989) The complete islet amyloid polypeptide precursor is encoded by two exons. FEBS Lett 247: 154-158

37. van Mansfeld ADM, Mosselman S, Höppener JWM et al. (1990) Islet amyloid polypeptide - structure and upstream sequences of the IAPP gene in rat and man. Biochim Biophys Acta 1087: 235240

38. Brinster RL, Chen HY, Trumbauer ME, Yagle MK, Palmiter RD (1985) Factors affecting the efficiency of intruding foreign DNA into mice by microinjecting eggs. Proc Natl Acad Sci USA 82: $4438-4442$

39. Laird PW, Zijderveld A, Linders K, Rudnicki M, Jaenisch R, Berns A (1991) Simplified mammalian DNA isolation procedure. Nucleic Acids Res 19:4293

40. Bell GI, Picket RL, Rutter WJ, Cordell B, Tischer E, Goodman HM (1980) Sequence of the human insulin gene. Nature 284: $26-32$

41. Stehouwer CDA, Lems WF, Fischer HRA, Hackeng WHL, Naass MAB (1989) Aggravation of hypoglycemia in insulinoma patients by the long-acting somatostatin analogue octreotide (Sandostatin). Acta Endocrinol 121: $34-40$

42. Bondar RJL, Mead DC (1974) Evaluation of glucose-6-phosphate dehydrogenase from Leuconostoc mesenteroides in the hexokinase method for determining glucose in serum. Clin Chem 20: 586-590

43. Lo D, Burkly LC, Widera G et al. (1988) Diabetes and tolerance in transgenic mice expressing class II MHC molecules in pancreatic beta cells. Cell 53: 159-168

44. Roman LM, Simons LF, Hammer RE, Sambrook JF, Gething M-JH (1991) The expression of influenza virus hemagglutinin in the pancreatic $\beta$-cells of transgenic mice results in autoimmune diabetes. Cell 61: 383-396

45. Hartter E, Svoboda T, Ludvik B et al. (1991) Basal and stimulated plasma levels of pancreatic amylin indicate its co-secretion with insulin in humans. Diabetologia 34: 52-54

46. Kreutter D, Orena SJ, Torchia AJ, Soeller W, Stevenson RW (1991) Amylin mRNA and plasma peptide levels in animal models of NIDDM. Diabetes 40: 159 A (Abstract)
47. Tokuyama Y, Kanatsuka A, Ohsawa H et al. (1991) Hypersecretion of islet amyloid polypeptide from pancreatic islets of ventromedial hypothalamic-lesioned rats and obese Zucker rats. Endocrinology 128: 2739-2744

48. Huang H-JS, Young AA, Koda JE, Tulp OL, Johnson MJ, Cooper GJS (1992) Hyperamylinemia, hyperinsulinemia, and insulin resistance in genetically obese LA/N-cp Rats. Hypertension 19: I-101-I-109

49. Alam T, Chen L, Ogawa A, Leffert JD, Unger RH, Luskey KL (1992) Coordinate regulation of amylin and insulin expression in response to hypoglycemia and fasting. Diabetes 41 : 508-514

50. DeFronzo RA, Bonadonna RC, Ferrannini E (1992) Pathogenesis of NIDDM - A balanced overview. Diabetes Care 15: 318368

51. Clark A, Wells CA, Buley ID et al. (1988) Islet amyloid, increased A-cells, reduced $\beta$-cells and exocrine fibrosis: quantitative changes in the pancreas of 'maturity onset' diabetic patients. Diabetes Res 9: 151-160

52. de Koning EJP, Bodkin NL, Hansen BC, Clark A (1993) Diabetes melitus in Macaca mulatta monkeys is characterized by islet amyloidosis and reduction in beta-cell population. Diabetologia 36: 378-384

53. Clark A (1992) Islet amyloid: an enigma of type 2 diabetes. Diabetes Metab Rev 8: 117-132

54. Clark A, Edwards CA, Ostle LR et al. (1989) Localisation of islet amyloid polypeptide in lipofuscin bodies and secretory granules of human $\beta$-cells and in islets of type 2 diabetic subjects. Cell Tissue Res 257: 179-185

55. Clark A, Morris JF, Scott LA et al. (1991) Intracellular formation of amyloid fibrils in $\beta$-cells of human insulinoma and pre-diabetic monkey islets. In: Natvig JB, Forre O, Husby G et al. (eds) Amyloid and amyloidosis. Kluwer, Dordrecht, pp 453-456

56. Höppener JWM, Oosterwijk C, Visser-Vernooy HJ, Lips CJM, Jansz HS (1992) Characterization of the human islet amyloid polypeptide/amylin gene transcripts - identification of a new polyadenylation site. Biochem Biophys Res Commun 189: 15691577

Received: 15 April 1993

and in revised form: 7 July 1993

Dr. J.W.M. Höppener

Institute of Molecular Biology

and Medical Biotechnology

Utrecht University

Padualaan 8

NL-3584 CH Utrecht

The Netherlands 